\title{
Increasing the Durability of Asphalt Pavement - the Road to Road Safety
}

\author{
Valentina Yadykina ${ }^{1}$, Anatoly Gridchin ${ }^{1}$, Anna Trautvain ${ }^{1 *}$, Rashid Sharapov ${ }^{2}$, and \\ Christina Pashkova ${ }^{1}$ \\ ${ }^{1}$ Belgorod State Technological University named after V.G. Shukhov, 46 Kostyukova str., Belgorod, \\ 308012, Russia \\ ${ }^{2}$ National Research Moscow State University of Civil Engineering, 26 Yaroslavskoye Shosse, \\ Moscow, 129337, Russia
}

\begin{abstract}
Based on literature data, the paper analyzed the impact of transport operational indicators related to the quality of road surface coverage on road safety. It presented the results of experimental studies on the effect of the road adhesion cationic thermostable additive on the properties of bitumen and asphalt concrete. The authors identified that the introduction of this additive leads to an increase in the viscosity and softening temperature of bitumen, its adhesion to mineral materials, which has a positive effect on strength, water resistance, shear stability, crack resistance, fatigue durability of asphalt concrete. The conclusion was made about the regularity of improving road safety, related to the improvement of the quality of the pavement, arranged from asphalt concrete with the application of the tested additive.
\end{abstract}

\section{Introduction}

The successful and safe operation of road transport depends to a large extent on the condition of existing highways and their technical parameters $[1,2,3]$. Actual conditions for the operation of highways differ from the calculated ones. As a consequence, the technical and economic indicators of the road transport work decreases, and traffic safety deteriorates. Every motor vehicle collision (MVC) is usually caused by an unfavorable combination of several factors closely related to each other, which makes it difficult to identify the true reasons for the analysis. One of the contributing factors is the unsatisfactory state of highways and streets $[2,4,5]$. From 10 to $15 \%$ of road accidents occur due to unsatisfactory road conditions. Studies show that drivers' mistakes in driving and traffic violations are the main cause of most accidents. But these violations can also be related to the shortcomings of highways, which in $50-80 \%$ of cases are one of the active causes, and in $15-20 \%$ of cases, the main cause of road accidents.

* Corresponding author: trautvain@,bk.ru 


\section{Material and methods}

The physicomechanical characteristics of bitumen were investigated according to the State General Education standard (SGE) number 22245-90, samples of asphalt concrete according to SGE 9128-2013, the cohesive strength of bitumen - according to EN 135882013.[17-19]

\section{Theory}

The main material for covering roads in most countries is asphalt concrete. It is known that many characteristics of asphalt-concrete mixtures depend on the quality of bitumen. The basis for a real increase in the physicomechanical properties and durability of road asphalt concrete was the introduction of modified bitumens $[7,8,9]$.

For the production of road bitumens, which meet high standards, in many countries the modification with their polyphosphoric acid is actively used, and also in combination with polymers [10].

Considerable interest is shown in the study of the mechanism of its interaction with various bitumens, which contributes to the development of new technologies. Scientific work in this field is represented by a large number of publications $[11,12,13,14,15]$.

The purpose of this work was to study the effect of bitumen, modified by the addition of RACThA (road adhesion cationic thermostable additive), developed and produced by "Selena" company on the basis of phosphoric acid esters and synthetic phospholipids, on the physical, mechanical and operational characteristics of asphalt concrete.

Based on the composition of the additive, it can be assumed that the mechanism of its action is the destruction of associates of asphaltenes into smaller particles; thanks to these processes, the fine-dispersed associates of asphaltenes interact more closely with the surface of the stone material. In addition, slowing the formation of a rigid spatial structure of asphaltenes will help reduce the aging rate of bitumen. Due to the presence of phosphoric acid esters in the additive composition, it is possible to expect that the bitumen rigidity will increase at high temperatures and decrease at low temperatures, it is also likely that the softening temperature of the modified bitumen will increase, and a significant increase in adhesion to the stone material is expected.

\section{Results and Discussion}

To conduct the study, bitumen oil road BND 60/90 of Saratov Refinery was used, the properties of which are presented in Table 1 .

As one can see, bitumen meets the requirements of regulatory documentation.

The influence of the tested additive on the change in the rheological, adhesive and cohesive properties of bitumen as well as on the properties of asphalt concrete on the variation in the compressive strength of the samples at test temperatures of 0,20 and $50^{\circ} \mathrm{C}$, as well as water saturation and prolonged water resistance after 15, 30, 60, 90 and 120 days, was studied. Concentration of the additive in accordance with the manufacturer's recommendations was $0.4 \%$.

The results of the bitumen tests with additives shown in Table 2 indicate that the introduction of the additive into the bitumen results in a significant change in the properties of the bitumen, such as penetration, softening temperature and extensibility. 
Table 1. Characteristics of bitumen, which is used

\begin{tabular}{|c|c|c|}
\hline Indicators & $\begin{array}{c}\text { Requirements of } \\
\text { GOST }\end{array}$ & $\begin{array}{c}\text { Actual } \\
\text { indicators }\end{array}$ \\
\hline $\begin{array}{c}\text { The penetration depth of the needle is } 0.1 \\
\mathrm{~mm}: \\
\text { at } 25{ }^{\circ} \mathrm{C} \\
\text { at } 0{ }^{\circ} \mathrm{C}\end{array}$ & $\begin{array}{c}61-90 \\
\text { not lesst han } 20\end{array}$ & 64 \\
22 \\
\hline $\begin{array}{c}\text { Extensibility, cm: } \\
\text { at } 25^{\circ} \mathrm{C} \\
\text { at } 0^{\circ} \mathrm{C}\end{array}$ & $\begin{array}{c}55, \text { not less } \\
3.5, \text { not less }\end{array}$ & $\begin{array}{c}71.4 \\
3.5\end{array}$ \\
\hline Softening temperature, ${ }^{\circ} \mathrm{C}$ & 47, not lower & 48 \\
\hline Brittleness temperature, ${ }^{\circ} \mathrm{C}$ & -15 , not higher & -22 \\
\hline Flash temperature, $0 \mathrm{C}$ & 230, not lower & 302 \\
\hline
\end{tabular}

Table 2. Change in the properties of bitumen when adding an additive

\begin{tabular}{|c|c|c|c|c|c|c|}
\hline \multirow[t]{2}{*}{ № } & \multirow[t]{2}{*}{ Additive } & \multicolumn{2}{|c|}{ Penetration } & \multirow{2}{*}{$\begin{array}{l}\text { Softening } \\
\text { temperatur } \\
\text { e, }{ }^{\circ} \mathrm{C}\end{array}$} & \multicolumn{2}{|c|}{ Extensibility } \\
\hline & & $25^{\circ} \mathrm{C}$ & $\mathbf{0}^{\circ} \mathrm{C}$ & & $25^{\circ} \mathrm{C}$ & $\mathrm{0}^{\circ} \mathrm{C}$ \\
\hline \multicolumn{2}{|c|}{ Requirements of GOST } & $61-90$ & notless20 & $\begin{array}{c}\text { not lower } \\
\text { than } 47\end{array}$ & $\begin{array}{l}\text { not less } \\
\text { than55 }\end{array}$ & $\begin{array}{l}\text { not less } \\
\text { than3,5 }\end{array}$ \\
\hline 1 & Without additive & 64 & 22 & 48 & 71,4 & 3,5 \\
\hline 2 & RACThA & 52 & 24 & 52 & 93,7 & 4,0 \\
\hline
\end{tabular}

As can be seen from Table 2, the addition of the additive leads to an increase in viscosity and softening temperature. It is important to note that at a temperature of $0{ }^{\circ} \mathrm{C}$, the penetration values increase slightly. Extensibility with the addition of RACThA also increases. All this indicates that bitumen with the addition of RACThA becomes somewhat more severe at high temperatures, while maintaining the required softness at low temperatures.

The influence of the additive on the adhesion of bitumen to stone materials was also studied. Figure 1 shows the effect of modified bitumen on adhesion to granite gravel.

It follows from the figure that the use of the additive positively affected the adhesion of bitumen to mineral material.

The effect of the additive was also evaluated by the change in bitumen cohesion, which was determined in accordance with EN 13588-2013. The results indicate an increase in bitumen cohesion when using the tested additive by $80 \%$.

In connection with the growth of adhesion and cohesion of bitumen, modified RACThA, asphaltic concrete prepared using this binder should be characterized by increased values of water, heat and frost resistance, as well as resistance to rutting.

Table 3 shows the effect of the additive on the physical and mechanical characteristics of asphalt concrete. 
a

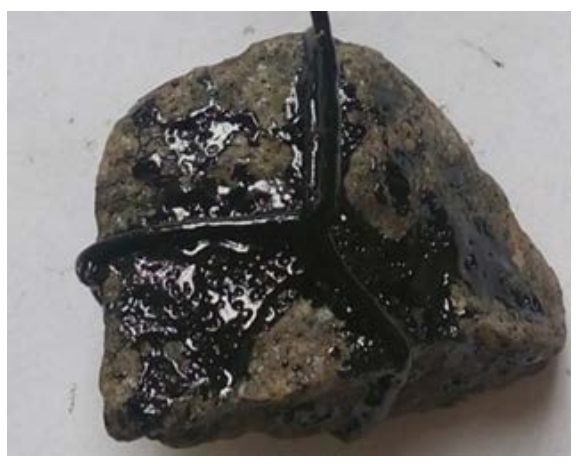

a - without an addictive; b

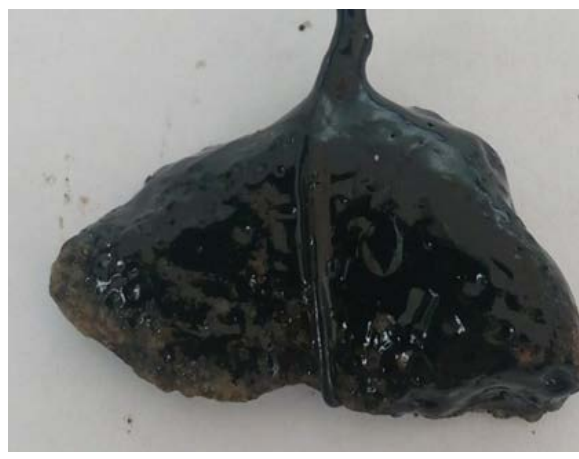

b - with RACThA

Fig. 1. Bonding of bitumen with granite gravel surface after boiling

The study of the influence of the additive on the physical and mechanical characteristics of asphalt concrete shows a positive effect on the properties of the latter. So the strength of asphalt concrete at $20{ }^{\circ} \mathrm{C}$ increased by $7 \%$ relative to the composite on bitumen without an additive, the strength at $50^{\circ} \mathrm{C}$ - by $17 \%$, the strength at $0{ }^{\circ} \mathrm{C}$ decreased by $12 \%$. The water saturation decreased by $39 \%$, which indicates a decrease in the porosity of asphalt concrete and an increase in resistance to seasonal temperature changes. In turn, the water resistance increased from 0.90 to 0.98 .

Table 3. Physical and mechanical characteristics of asphaltic concrete modified by the addition of RACThA

\begin{tabular}{|c|c|c|c|}
\hline $\begin{array}{c}\text { Physical and mechanical } \\
\text { characteristics }\end{array}$ & \begin{tabular}{|l|} 
Requirements of \\
GOST 9128-2013 \\
\end{tabular} & $\begin{array}{c}\text { Without an } \\
\text { addictive }\end{array}$ & RACThA \\
\hline $\begin{array}{l}\text { The limit of compressive strength, } \\
\text { MPa: } \\
\text { at } 20 \mathrm{oC} \\
\text { at } 50 \mathrm{oC} \\
\text { at } 0 \mathrm{oC}\end{array}$ & $\begin{array}{l}\text { from } 2.2 \\
\text { from } 1 \\
\text { to } 12\end{array}$ & $\begin{array}{c}3.9 \\
1.2 \\
11.3\end{array}$ & $\begin{array}{l}4.2 \\
1.4 \\
9.9\end{array}$ \\
\hline $\begin{array}{l}\text { The limit of the strength of water- } \\
\text { saturated samples, MPa }\end{array}$ & - & 3.5 & 4.1 \\
\hline Water saturation & $1.5-4.0$ & 3.3 & 2.0 \\
\hline Water resistance & 0.85 & 0.90 & 0.98 \\
\hline
\end{tabular}

The change in the long-term water resistance after $0,15,30,60,90$ and 120 days of asphalt concrete with additives is shown in Figure 2.

In general, the long-term water resistance of asphalt concrete with the use of the additive significantly increased, which can be explained by the improvement of the adhesion of bitumen to the mineral materials of the composite. So, compared with the initial value, the water resistance after 15 days of asphalt concrete on the original bitumen and bitumen with the additive decreased by 15.6 and by $8.2 \%$, respectively.

After 30 days, the water resistance value of the composite with the additive was 0.86 , whereas without the additive was only 0.67 . With the continuation of the test, the trend persisted. Water resistance after 120 days of testing of asphalt-concrete samples on the original bitumen decreased by $44 \%$, while on bitumen, modified by RACThA, only by $30 \%$. 
Thus, the RACThA additive significantly increased the water resistance of asphalt concrete, which should positively affect the durability of the road surface.

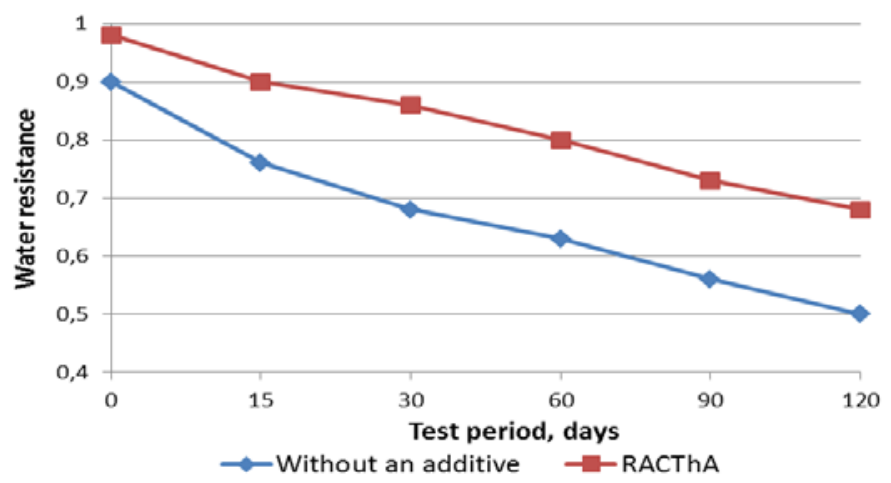

Fig. 2. The effect of additives on the long-term water resistance of asphalt concrete

The presence of ruts and cracks in the road surface can make it difficult to maintain a safe trajectory along the road [16]. Water accumulating in ruts and cracks in the road surface increases the risk of slipping. Large potholes on the road surface can lead to premature deterioration or breakdown of the car, or loss of driver control over driving.

In this regard, the indicators of asphalt concrete are very important from the viewpoint of ensuring the strength and reliability of pavement, shear resistance and crack resistance.

The results of determining these indicators are given in Table 4.

Table 4 shows that the shear stability indicators: the coefficient of internal friction and shear adhesion at $50^{\circ} \mathrm{C}$ of asphalt concrete on the modified binder increased in comparison with asphalt concrete on bitumen BND 60/90 without an additive. Figure 3 shows the change in these indicators in percent.

Table 4. Characteristics of asphalt concrete

\begin{tabular}{|c|c|c|c|}
\hline Characteristics & $\begin{array}{c}\text { Characteristics } \\
\text { of GOST 9128- } \\
\mathbf{2 0 1 3}\end{array}$ & $\begin{array}{c}\text { BND } \\
\mathbf{6 0 / 9 0}\end{array}$ & $\begin{array}{c}\text { Bitumen } \\
\text { with } \\
\text { RACThA }\end{array}$ \\
\hline $\begin{array}{c}\text { Shear resistance: } \\
\text { coefficient of internal } \\
\text { friction, not less than } \\
\text { adhesion at shear at } \\
+50 \text { oC, MPa, not less } \\
\text { than }\end{array}$ & 0.81 & 0.83 & 0.94 \\
\hline Crack resistance & 0.35 & 0.37 & 0.42 \\
\hline
\end{tabular}




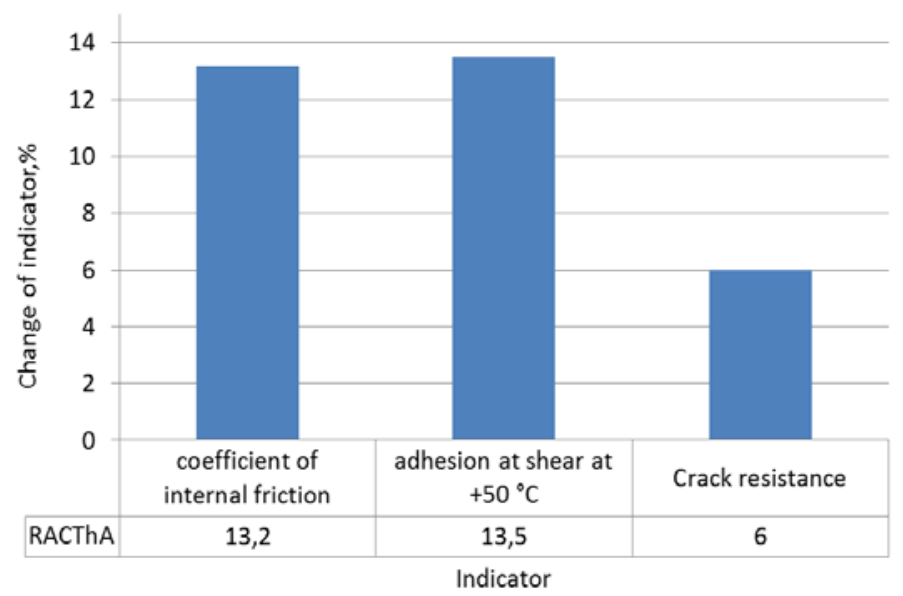

Fig. 3. Change in shear stability and crack resistance

Figure 3 shows that the shear stability indicators increased by $13 \%$, which should positively affect the quality of the asphalt-concrete covering. Shear resistance is the ability to resist tangential stresses, and, consequently, with an increase in the shear stability indicator, the asphalt concrete will be more resistant to rutting. This was to be expected, since in previous studies of standard physical and mechanical properties of asphalt concrete, the strengths at 20 and $50^{\circ} \mathrm{C}$ increased by 7 and $17 \%$, respectively.

Crack resistance, which characterizes the resistance to tensile strength at low temperatures, increased by $6 \%$, which is quite logical, since the strength of asphalt concrete at $0^{\circ} \mathrm{C}$ decreased by $12 \%$. It follows that asphalt concrete will be less susceptible to mechanical deformations at negative temperatures, which will positively affect the operational properties of asphalt concrete on the modified binder. The growth of these indicators can be explained by the presence of phosphoric acid in the composition of the RACThA.

The next stage of the research was the testing of fatigue durability, the rigidity modulus and the resistance to rutting. These characteristics, in particular, the index of fatigue durability, will allow to predict an increase in the operational properties of the asphaltconcrete covering.

Table 5. Characteristics of asphalt concrete

\begin{tabular}{|c|c|c|}
\hline \multirow{2}{*}{ Indicator } & \multicolumn{2}{|c|}{ Value } \\
\cline { 2 - 3 } & $\begin{array}{c}\text { BND } \\
\mathbf{6 0 / 9 0}\end{array}$ & $\begin{array}{c}\text { BND 60/90 with } \\
\text { the addition of } \\
\text { RACThA }\end{array}$ \\
\hline $\begin{array}{c}\text { Hardness module, } \\
\mathrm{MPa}\end{array}$ & 4660 & 4392 \\
\hline Fatigue durability & 81000 & 130000 \\
\hline Depth of track, mm & 20 & 14 \\
\hline
\end{tabular}

As can be seen from Table 5, the asphaltic concrete strength modulus with RACThA added decreased by $5 \%$ compared to asphalt concrete on the original bitumen. Fatigue durability increased 1.6 times, which suggests that the overhaul durability of the asphalt covering will increase. The depth of track through 20 thousand passes was reduced by $30 \%$, compared to asphalt on the original bitumen of BND 60/90. 


\section{Conclusion}

Thus, the use of the RACThA additive improves such operational characteristics of asphalt concrete as water resistance, rigidity module, resistance to rutting, fatigue durability, which will lead to improved road surface quality.

From the results of the research it is known that a general improvement in the state of the road reduces the number of road accidents with injuries by approximately $20 \%$. The number of accidents with material losses is reduced by $5 \%$. In this regard, it is reasonable to assume that improving the quality of the road covering, constructed from asphalt concrete with the application of the additive to be tested, will lead to an increase in road safety and a reduction in the number of accidents.

The article was prepared within the framework of the program for the development of the key university on the basis of the BSTU named after. V.G. Shukhov.

\section{References}

1. B. E. Quinn, S. E. Hildebrand, Effect of road roughness on vehicle steering. Highway Research Record, 471 (1973)

2. A. Ihs, H. Velin, M. Wiklund, The Influence of Road Surface Condition on Traffic Safety: data from 1992-1998. VTI MEDDELANDE, 909 (2002)

3. A. His, The influence of road surface condition on traffic safety and ride comfort. 6th International Conference on Managing Pavements 19-24 October 2004. Brisbane Convention \& Exhibition Centre, Queensland Australia. - Statensvägochtransportforskningsinstitut, pp. 11-21 (2005)

4. P. Cairney, P. Bennett, An exploratory study of surface characteristics and crash occurrence on selected roads in Australia, ARR 382 (2013)

5. C. J. Bester, The effect of road roughness on safety. 82nd Annual Meeting of the Transportation Research Board, Washington, DC (2003)

6. Federal'nye dorogi Rossii. Transportno-jekspluatacionnye kachestva i bezopasnost' dorozhnogo dvizhenija (statisticheskii sbornik): 2011 Statistical analytical collection. Federal roads of Russia.Transport-operational qualities and safety of traffic: (Data Book).Moscow:DorTransMedia.176 p. (2011)

7. V.A. Zolotarev, Bitumy, modificirovannye,polimerami i dobavkami. Izbrannye trudy Bitumen modified with polymers and additives. Selected works.SPb., 2, 149 p. (2013)

8. A.I. Trautvain, V.V. Yadikina, D.V. Zemlyakova, Yu.P. Chistyakov, Vlijanie dobavok Evotherm, Azol 1007 i Adgezol 3-td na svojstva bituma. Dorogi i mosty, 1, pp. 320-333 (2015)

9. V.V. Yadykina, A. M. Gridchin, A. I. Trautvain, V.S. Kholopov, Energy Saving Additives «RAA WAC» for Production of Warm Asphalt Concrete. Key Engineering Materials, 677, pp 273-277 (2016)

10. R. Maldonado, Polyphosphoric acid in bitumen. Avtomobil'nye dorogi, 5, pp. 77-79 (2011)

11. S.-C. Huang, T. F. Turner, F. P. Miknis, K. P. Thomas, Long-Term Aging Characteristics of Polyphosphoric Acid-Modified Asphalts. In Transportation Research Record: Journal of the Transportation Research Board, Transportation Research Board of the National Academies, Washington, D.C., 2051, pp. 1-7 (2008) 
12. S. Terry, Arnold, Jack Youtcheff, Needham, P. Susan, Use of Phosphoric Acid as Modifier for Hot-Mix Asphalt. Presented at the Polyphosphoric Acid Modification of Asphalt Binders, January, pp. 40-51 (2012)

13. S. Ho, L. Zanzotto, and D. MacLeod, Impact of Chemical Modification on Composition and Properties of Asphalt Binders. Proc., Canadian Technical Asphalt Association, 46, pp. 153-170 (2001)

14. C. Giavarini, D. Mastrofini, M. Scarsella, Macrostructure and Rheological Properties of Chemically Modified Residues and Bitumens. Energy \& Fuels, 14, pp. 495-502 (2000)

15. G. Baumgardner, J.-F. Masson, J. Hardee, A. Menapace, Polyphosphoric Acid Modified Asphalt: Proposed Mechanisms. Journal of Association of Asphalt Paving Technologists, 74, pp. 283-285 (2005)

16. J. Törnros, C.G. Wallman, The influence of pavement ruts on driver behaviour. VTI meddelande, 940 (2003)

17. SGE 22245-90. Bitumens oil road viscous. Technical conditions. Enter 01/01/1990. Moscow: State Standard of Russia: Standards Publishing House. P. 21 (1990)

18. SGE 9128-2013. Asphalt road, airfield and asphalt concrete mixes. Technical conditions. Enter 01/01/2013. Moscow: State Standard of Russia: Standards Publishing House. P.39 (2013)

19. EN 13588-2013. BITUMENS AND BITUMINOUS BINDERS. Determination of the cohesion of bituminous binders using a pendulum. Enter 01/01/2015. Moscow:

Standartinform Publishing House. P. 12 (2014) 